EDITORIAL

\section{O NOVO PÚBLICO DA RAE}

Para o ano de 1998, foram estabelecidas novas metas para a RAE com o objetivo de acompanhare subsidiar as mudanças que deverâo ocorrer na EAESP. Em primeiro lugar, projetamos um salto no número de assinantes, o que implicará um exame da estratégia de divulgaçào. Em segundo lugar, ainda que năo menos importante, os custos serăo o objeto de nova avaliaçäo e de monitoramento. Finalmente, embora a longo prazo, será reexaminado todo o composto do produto. Nessa logica, a RAE buscara ser um agente de "fidelizaçäo" do leitor que tenha algum vínculo com a EAESP elou com o projeto de nossa Escola de modo a comecarmos a esboçar o que devera ser o futuro da FGVISP. Nessa direção, nossos assinantes seräo convida. dos a responder uma pesquisa que visa a aprimorar nosso conhecimento sobre as preferências de nossos leitores. Algumas iniciativas jâ tomadas em 1997 deverão ser expandidas (veiculaçâo de anúncios) e outras incorporadas de lorma definitiva (internacionalização da Revista). Para esta ediçâo $2 / 98$ reservamos alguns artigos que foram selecionados entre os melhores enviados. $O$ artigo do Prof. Jasé Enesto Lima Gonçalves permite aprofundar um tema que é sempre atual em vista das constantes mudanças. Ainda na seçăo Organizaçăo, Recursos Humanos e Planejamento, publicamos a artigo de Eunice M. L. Soriano de Alencar que examina as condições que favorecem a criatividade nas organizações. Para a seção Administração Mercadológica, escolhemos um artigo bastante objetivo, de autoria de Rubens C. Santos e Virgínia M.F. de Castro, sobre desenvolvimento de embalagens. Em Finanças, o tema em destaque é a influência das opçōes reais na avaliação dos contratos de leasing. Dando continuiddade ao artigo anterior, Alberto Luiz Albertin e Rosa Maria Moura aprofundam a discussão sobre comércio eletrónico, enfatizando os aspectos relativos à privacidade e à segurança das informaçōes. Finalmente, a área de Admínistraçăo Hospitalar apresenta o artigo sobre análise do custoleficácia das intervençōes em organizaçōes de saúde. A RAE Lightpublica artigos de John Kasarda sobre logistica e de Maria Ester de Freitas sobre a familia no contexto do mundo do trabaiho.

\section{Roberto Venosa} Editor e Diretor

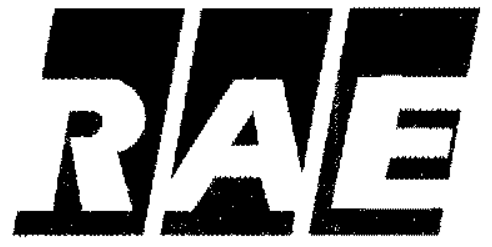

VOLUME 38 NUMERO 2

ABR./JUN. 1998

\section{Organização, Recursos Humanos e Planejamento}

\section{A necessidade de reinventar as \\ empresas}

José Emesto Lima Gonçalves

Para aigumas empresas a adaptaça aos nowos tempos c inevitźvel, uma questáo de vida e morte. Para outras, a adaptaçâa é uma recomendaçăo, uma medida de segurança. As empresas contemporàneas estão precisando mudar em tunça de pressöes externas e internas inéditas tanto na variedade quanto na intensidade e akguns eventos estâo sinalizando a chegada da nova empresa. Novas premissas, adequadas a novos fatores, devem orientar o projeto dus empresas destinadas a sobreviver e prosperar nos novos tempos.

To some companies, adapting to new times is inevitable, a ifo or death decision. To others it is recommended as a precaution. Contemporany companies have to change because of external and intemai pressures that are novel both in intensity and variety and we have seen signs of the arrival of the new enterprise. New premises, more adequate to these new factors, shall guide the design of companies that are to survive and row in these new times.

\section{Promovendo um ambiente favorável à criatividade nas organizações}

Eunice M. L. Soriano de Alencar

Após destacar que a criatividate nêo deve ser vista apenas como um fenômeno de natureza intrapsiquica, uma vez que multos säo os fatores ambientais que infuenctam e motilizam o potencjal criativo, säo abordados, neste artigo, distintos aspectos relativos a trós eixos centrais: as caracteristicas pesscais que se relacionam à criativdade, dando enfíase tanto a aributcs pessoais favoráveis como a outros, desfavoraves; alguns fatores do contexto social que aletama produço criatia, cono valores, tradicoes es sistemas de incentivo e puniçoes; $\theta$ as caracteristicas de um ambiente de trabaho que se constituem ora como estimulos, or como obstáculos á criatividade.

Creatity is fot an intrapsychic phenomenon. it is strongly infuenced and mobilized by environmental lactors. This anticle anahses three different groups of factors which affect creativity. The first one is the personal attributes which favour or inhibit crealivity. The second is some characteristics of the social contexts such as values, traditions, incentive and punishnyent system, which influence the creative behaviour. A third group of factors refers to the characteristics of the work environment which affect creativity. Both the stimulant factors and the inibiting factors are described. 